Sains Malaysiana 50(12)(2021): 3537-3545

http://doi.org/10.17576/jsm-2021-5012-06

\title{
Effects of Traditional and Convenient Edible Bird's Nest on Spatial Learning of Male Sprague-Dawley Rats
}

(Kesan Sarang Burung Tradisi dan Mudah-Masak ke atas Pembelajaran Reruang Tikus Sprague-Dawley Jantan)

Haziq Kamal, Khidhir Kamil, Nelson Tan Kar Wai, Abdul Latif NoOr bin Amiruddin, ManmeEt Kaur

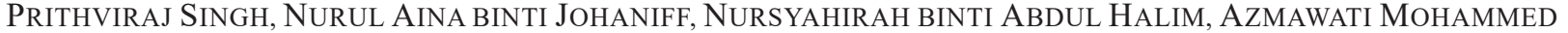
NAWI, CHUA KIEN HUI \& JAYA KUMAR*

\begin{abstract}
Consumption of edible bird's nest (EBN) has been a common practice for the health benefits it is believed to provide. Hence, this study aimed to investigate the effects of both traditional edible bird's nest (TEBN) and convenient edible bird's nest (CEBN) on the spatial learning of male Sprague Dawley rats in a radial arm maze (RAM). A total of 24 male rats (270-300 g) were allocated into three groups based on diet given namely pellet only (control group), pellet mixed with $T E B N(300 \mathrm{mg} / \mathrm{kg})$ and pellet mixed with CEBN $(300 \mathrm{mg} / \mathrm{kg})$. The rats were fed with the aforementioned diet throughout the study for 42 days and exposed to RAM for spatial learning assessments which consisted of shaping (3 days), acquisition (8 days) and retention (1 day) trials. In the acquisition trials, CEBN reduced working memory error (WME) on day 5 compared to control, and day 6 compared to the TEBN group. TEBN markedly reduced reference memory error (RME) on day 1 and 8, time spent (day 3) and percentage of correct choices made (day 3) during the acquisition trials compared to CEBN. TEBN and CEBN significantly reduced WME, however, only CEBN increased RME during the retention trial. CEBN significantly affected the total entries produced in the RAM which indicated the non-specific effects of CEBN on the locomotion of the rats. Our findings suggested that TEBN may work better than CEBN in improving spatial learning considering the fact that CEBN markedly reduced the locomotion of the rats during the retention trial.
\end{abstract}

ABSTRACT

Keywords: Cognition; radial arm maze; spatial memory; supplement; working memory

ABSTRAK

Pengambilan 'sarang burung Walit' (EBN) telah menjadi amalan biasa oleh kerana ia dipercayai mempunyai manfaat kesihatan. Oleh itu, kajian ini bertujuan mengkaji kesan 'sarang burung Walit tradisi (TEBN) dan 'sarang burung Walit mudah-masak' (CEBN) ke atas pembelajaran reruang tikus Sprague Dawley jantan dalam lorongan keliru lengan radial (RAM). Sebanyak 24 ekor tikus jantan (270-300 g) telah dibahagikan kepada tiga kumpulan berdasarkan diet yang diberikan iaitu pelet sahaja (kumpulan kawalan), pelet yang dicampurkan dengan TEBN (300 $\mathrm{mg} / \mathrm{kg}$ ) dan pelet yang dicampurkan dengan CEBN $(300 \mathrm{mg} / \mathrm{kg})$. Kesemua tikus telah diberi diet tersebut sepanjang kajian selama 42 hari dan didedahkan kepada RAM untuk penilaian pembelajaran reruang yang terdiri daripada percubaan pembentukan (3 hari), perolehan (8 hari) dan pengekalan (1 hari). Dalam percubaan perolehan, CEBN telah mengurangkan ralat ingatan kerja (WME) pada hari ke-5 berbanding kawalan dan hari ke-6 berbanding kumpulan TEBN. TEBN telah mengurangkan ralat ingatan rujukan (RME) dengan ketara pada hari pertama dan ke-8, masa yang diambil (hari ke3) dan peratusan membuat pilihan yang betul (hari ke-3) semasa percubaan perolehan berbanding CEBN. TEBN dan CEBN telah mengurangkan WME secara signifikan, namun hanya CEBN yang meningkatkan RME semasa percubaan pengekalan. CEBN mempengaruhi keseluruhan entri yang dihasilkan dalam RAM secara signifikan yang menunjukkan kesan tidak khusus CEBN pada pergerakan tikus. Penemuan ini mencadangkan TEBN mungkin berfungsi lebih baik daripada CEBN dalam meningkatkan pembelajaran reruang memandangkan CEBN telah mengurangkan pergerakan tikus secara signifikan semasa percubaan pengekalan.

Kata kunci: Ingatan kerja; ingatan reruang; kognisi; lorongan keliru lengan radial; suplemen

\section{INTRODUCTION}

Edible bird's nest (EBN) is made using salivary secretions of two sublingual salivary glands of certain types of swiftlets from three genera namely Collocalia (non-echolocating swiftlets), Aerodramus (echolocating swiftlets) and Hydrochous (giant swiftlets). The swiftlets 
mainly found in Malaysia are Aerodramus fuciphagus (Lee et al. 1996). EBN consists of carbohydrates (9\% sialic acid, $7.2 \%$ galactosamine, $5.3 \%$ glucosamine, $16.9 \%$ galactose, and $0.7 \%$ fucose), and glycoproteins (Kathan \& Weeks 1969). EBN also contains essential trace elements such as calcium, sodium, magnesium, zinc, manganese, and iron (Marcone 2005) and amino acids such as glutamic acid (9.61\%), aspartic acid (6.34\%), lysine (5.44\%) and leucine (5.30\%) (Halimi et al. 2014). Like many medicinal plants (Hambali et al. 2021; Hamid et al. 2020; Kamil et al. 2020, 2018; Lina et al. 2018; Prom-in et al. 2020), the EBN of A. fuciphagus has been believed to have health benefits (Chua et al. 2021), forming the basis of a multi-billion-dollar industry worldwide. EBN is known to enhance skin complexion (Matsukawa et al. 2011), alleviate asthma, strengthen the immune system (Chau et al. 2003) and also has pro-proliferative effects on corneal keratocytes (Argüeso et al. 2003), and antioxidative (Norhayati et al. 2010) and bone-strengthening effects (Matsukawa et al. 2011).

It was assumed that the use of sialic acid, one of the active components of EBN, might benefit infants in both neurological and intellectual needs (Chau et al. 2003). The other major glyconutrients present in $\mathrm{EBN}$, such as $7.2 \% \mathrm{~N}$-acetylgalactosamine (GalNAc), 5.3\% $\mathrm{N}$-acetylglucosamine (GlcNAc), 16.9\% galactose and $0.7 \%$ fucose (Dhawan \& Kuhad 2002) have also been associated with neurological benefits. GalNAc enhances synaptic functions, and GalNAc deficiency leads to severe memory deficits (Argüeso et al. 2003). In a recent study, EBN was shown to improve the spatial learning of ovariectomised rats via hippocampal orthodox of yeast silent information regulator (SIRT1) (Hou et al. 2017). SIRT1 is vital for modulation of axonal and dendritic growth, neuronal plasticity and protection against neurodegeneration and cognitive decline ( $\mathrm{Ng}$ et al. 2015). Based on these findings, it is noteworthy to investigate whether EBN will have similar favourable outcomes in learning and memory of the general population, which at preclinical level can be tested using treatment-naive animals.

In this study, adult male rats were fed with a diet containing convenient (CEBN) and traditional EBN (TEBN) (which differed in preparation techniques). The rats were then exposed to an eight radial arm maze (RAM), and their cognitive performance in the maze was compared with a control group to assess if EBN could improve spatial learning of normal animals. The RAM was chosen for this study as it is one of the best means to test short-term memory in rats besides the Morris water maze (Hodges 1996). Compared to the Morris water maze,
RAM is cheaper and simpler to set up (Quillfeldt 2006) and less invasive.

\section{MATERIALS AND Methods}

\section{ANIMAL PREPARATION}

Twenty-four Sprague Dawley male rats (8 weeks old) weighing 270 to $300 \mathrm{~g}$ were individually housed under controlled conditions (12 h light/12 h dark cycle, 21-22 ${ }^{\circ} \mathrm{C}, 40-50 \%$ humidity). For the first 7 days, the animals were allowed to adapt to the surroundings with water and food provided ad libitum. All the experimental animal procedures in this study were approved by Universiti Kebangsaan Malaysia Animal Ethics Committee (UKMAEC). The animals were allocated into three groups ( $n=8$ /group) where Group 1 consisted of a control group fed with convenient rat pellet, Group 2 consisted of rats that were given pellet mixed with TEBN $(300 \mathrm{mg} / \mathrm{kg}$ ) and Group 3 consisted of rats that were fed with pellets mixed with CEBN $(300 \mathrm{mg} / \mathrm{kg})$. The experimental groups were fed with pellets containing EBN $(300 \mathrm{mg} / \mathrm{kg})$ for 42 days throughout the study (during 30 days of feeding period and 12 days of RAM trials). A prior study reported that EBN improved spatial learning of ovariectomised rats in Morris's water maze following 12 weeks of treatment with a diet containing $\operatorname{EBN}(0.3,0.6$, and $1.2 \mathrm{~g} /$ $\mathrm{kg})$. The highest dosage of EBN $(1.2 \mathrm{~g} / \mathrm{kg})$ improved the learning performance better than oestrogen, whereas the ovariectomised rats treated with $0.3 \mathrm{~g} / \mathrm{kg}$ of EBN performed almost as well as the control group. Based on these findings, the low dosage of EBN $(0.3 \mathrm{~g} / \mathrm{kg})$ was employed in our study as the dosage of choice (Hou et al. 2017).

\section{PREPARATION OF EBN: TRADITIONAL VS CONVENIENT}

EBN was provided by Glycofood Sdn Bhd (Kuala Lumpur, Malaysia). TEBN was prepared from raw EBN obtained from the swiftlets' home in Triang, Pahang. Collected raw EBN was soaked in clean, filtered water for one hour to be softened and swollen. Feathers and other impurities within the raw EBN were removed manually with forceps. The cleaned EBN was then air-dried, moulded into cup shapes and packed; similarly, CEBN was prepared from the same source. Upon removal of impurities, EBN was steam-cooked for $30 \mathrm{~min}$, which was then followed by moulding of EBN into cup shapes and freeze-drying for 3 days. After freeze-drying, EBN was packed and sent for further processing. Prior to the treatment, the EBN was ground to powder form using a food grinder and mixed with food pellets based on the dosages described previously. 


\section{SPATIAL LEARNING IN THE 8 RAM}

The RAM consisted of equally spaced arms (length: $60 \mathrm{~cm}$; width: $10 \mathrm{~cm}$; the height of side walls: $15 \mathrm{~cm}$ ) radiating from an octagonal central platform $(22 \mathrm{~cm}$ wide) and elevated $80 \mathrm{~cm}$ from the ground. A food well (width: $1 \mathrm{~cm}$; depth: $0.5 \mathrm{~cm}$ ) was placed at $1 \mathrm{~cm}$ from the end of each arm. The RAM was placed in an enclosed room under dim homogenous fluorescent bulbs. Visually distinct cues (cardboard paper shaped as diamond, square, oval and star) were placed near the baited arms during the experiments. Animal behaviour was observed via a video camera mounted above the centre of the maze. The 8 RAM protocol was based on Valladolid-Acebes et al. (2011).

\section{SHAPING TRAINING}

Six days prior to shaping training, all rats were handled for 5 min daily. During the first phase of the experiment, the animals were allowed to acclimatise to the RAM. During the training session, the rats were allowed to explore and eat all the food pellets scattered throughout the maze (all eight arms) for 10 min each day for 3 days. On each successive day, the number of pellets was reduced and placed closer to the end of each arm. At the end of the shaping training (day 3), the food pellet was placed only in the food wells.

\section{ACQUISITION AND RETENTION TRIALS}

Prior to the acquisition trials, the RAM was cleaned with $10 \%$ ethanol, and four of the eight arms ( $\operatorname{arm} 2,3,6$ and 8) were baited with food reinforcement together with the cues (cardboard paper shaped as diamond, square, oval and star). At the beginning of each session, the rat was placed in the centre of the octagon and allowed a free choice. An arm choice was recorded if the rat ate the bait or reached the end of an arm. Entry to the baited or unbaited arm was recorded when all four paws of the rat had crossed three-quarters of the arm. The trial was continued until the rat entered all four baited arms or after $5 \mathrm{~min}$ had elapsed. After the trial, the rat was returned to the home cage and was given a second trial consecutively ( $2 \mathrm{~min}$ after the first trial), after the maze had been cleaned with $10 \%$ ethanol and re-baited. The retention trial (where arms were baited similar to the acquisition trials) was carried out as a single trial session $24 \mathrm{~h}$ after the completion of the last acquisition trial.

\section{EVALUATION CRITERIA}

An entry into an unbaited arm was known as reference memory error (RME), and re-entry into a baited arm was perceived as working memory error (WME). The percentage of correct choices was calculated by the number of entries to the baited arms divided by the number of total entries in $5 \mathrm{~min}$ of a single trial. The success rate was calculated by dividing the total baited arm entries by 4 (total number of baited arms). The mean time spent in two consecutive acquisition trials (from day 1 to 8 ) and retention trials was evaluated and compared across the groups. The median of RME, mean of WME, total entries, percentage of correct choice, success rate, in two consecutive acquisition trials (from day 1-8) and retention trials were assessed and compared across the groups. Total entries produced in the RAM were indicative of the rats' locomotion throughout the study.

\section{STATISTICAL ANALYSIS}

Data analysis was carried out using IBM Statistical Package for Social Sciences (SPSS) version 25.0. The data were represented by mean \pm standard deviation for RME, total entries and percentage of correct choice. The data were analysed by repeated measures of ANOVA and post-hoc Bonferroni test. Analyses of WME and time spent in RAM during acquisition trials were analysed by Friedman's test, and Kruskal-Wallis test with posthoc Dunn's test. The data were represented by median and lower (LL) and upper limit (UL) (Me [LL, UL]). The data from the retention trials were analysed using oneway ANOVA. A p-value of less than 0.05 is considered statistically significant.

\section{RESULTS}

\section{EFFECTS OF TEBN AND CEBN ON WORKING MEMORY ERROR}

The effect of EBN on WME performance during the acquisition trial as in Figure 1(A) showed that TEBN had no significant effect on WME compared to the control group $(p>0.05)$. However, CEBN-fed rats showed significantly less WME compared to control on day 5 $(\mathrm{p}<0.01)$ and TEBN group on day $6(\mathrm{p}<0.01)$. For the retention trial, both TEBN $(0.62 \pm 0.26)$ and CEBN $(0.43$ $\pm 0.25)$ significantly reduced WME compared to the control group $(1.50 \pm 0.42)(\mathrm{p}<0.0001)$ (Figure $1(\mathrm{~B}))$.

\section{EFFECTS OF TEBN AND CEBN ON REFERENCE MEMORY ERROR}

The effect of EBN on RME throughout the acquisition 
A

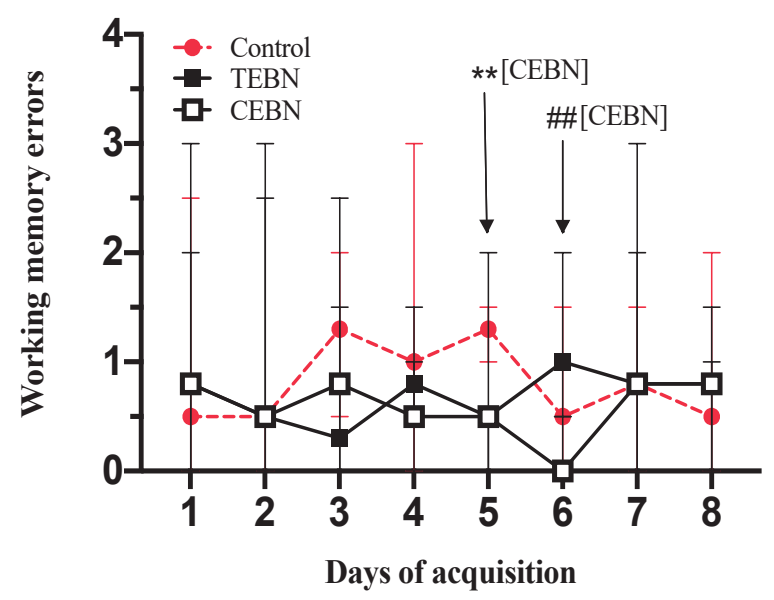

B

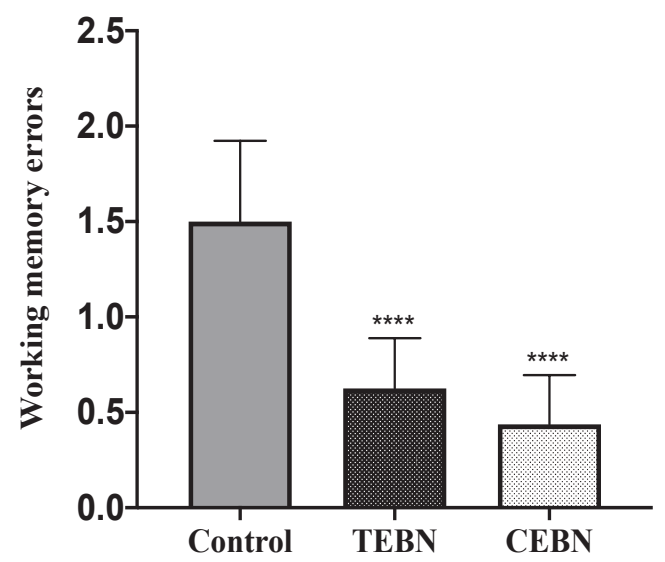

FIGURE 1. The effect of EBN on WME during acquisition (A) and retention (B) trials. The ordinate axis is the median and lower (LL) and upper limit (UL) (Me [LL, UL]) of the WME. Friedman test was used to analyse significance within the groups. Kruskal-Wallis test showed significant changes in WME on day 5 and 6 for CEBN; $* *=p<0.01$ compared to control and $\# \#=p<0.01$ compared to TEBN by post hoc Dunn's test. The WME during retention trial was analysed by One-way ANOVA and post hoc Tukey test; **** $=\mathrm{p}<0.0001$ compared to control

phase showed that during the acquisition period, there was no significant 'within-group' differences $(p>0.05)$ (Figure 2(A)). However, across the groups, animals fed with CEBN made more RME on day 1 compared to control $(\mathrm{p}<0.01)$ and TEBN $(\mathrm{p}<0.01)$. On day 2 , TEBN $(\mathrm{p}<$
$0.01)$ and CEBN $(\mathrm{p}<0.01)$ fed rats recorded more RME than the control group, and on day 3 , the CEBN $(p<0.05)$ group made more RME than the control group. During the retention trial, the CEBN $(4.75 \pm 0.72)$ produced significantly higher RME compared to both the control
A

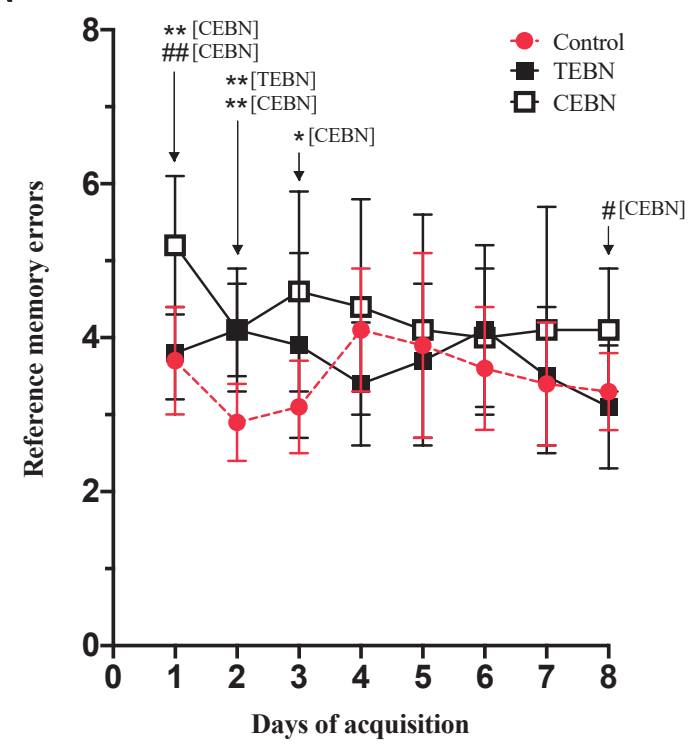

B



FIGURE 2. The effect of EBN on RME during acquisition (A) and retention (B) trials. Repeatedmeasure of ANOVA and post hoc Bonferroni test were used to analyse RME recorded during the acquisition trials. Post hoc Bonferroni test showed significant changes in RME at days 1, 2, 3 and 8; $*=\mathrm{p}<0.05, * *=\mathrm{p}<0.01$ compared to control and $\#=\mathrm{p}<0.05$, \#\# $=\mathrm{p}<0.01$ compared to TEBN. The RME during retention trial was analysed by One-way ANOVA and post hoc Tukey test; *** $=\mathrm{p}$ $<0.001$ compared to control and \#\#=p<0.01 compared to TEBN 
$(3.75 \pm 0.25)(\mathrm{p}<0.001)$ and the TEBN $(4.00 \pm 0.18)(\mathrm{p}$ $<0.01$ ) groups (Figure 2(B)).

\section{EFFECTS OF TEBN AND CEBN ON TOTAL ENTRIES}

The total entries produced in the RAM during acquisition and retention trials found a profound 'within-group' difference among the control animals throughout the acquisition trials $(p<0.01)$ (Figure $3(\mathrm{~A})$ ). However, no 'within-group' differences were noticed in CEBN or TEBN groups during the acquisition trials $(\mathrm{p}>0.05)$. Across the groups, we noticed no significant differences during the acquisition trials $(\mathrm{p}>0.05)$ (Figure 3(A)). During the retention trial, the CEBN group produced

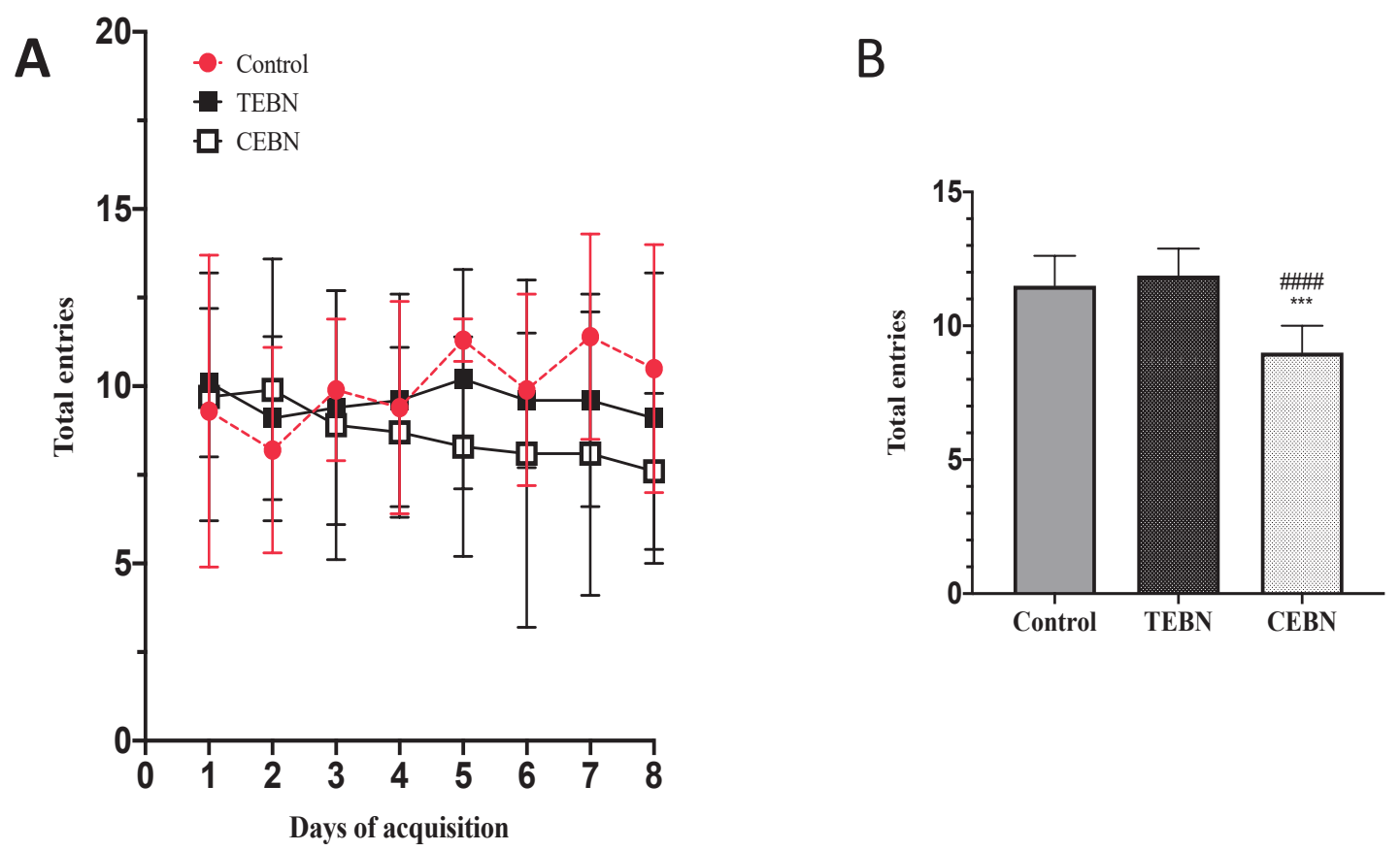

FIGURE 3. The effect of EBN on total entries in the spatial memory acquisition (A) and retention (B) trials. Data recorded during acquisition trials were analysed using Repeated-measure of ANOVA $(\mathrm{p}<0.05)$. The total entry during retention trial was analysed by One-way ANOVA and post hoc Tukey test; *** $=\mathrm{p}<0.001$ compared to control and \#\#\# = p $<0.0001$ compared to TEBN

significantly fewer entries $(9 \pm 1)$ compared to the control $(11.5 \pm 1.11)(\mathrm{p}<0.001)$ and TEBN $(11.87 \pm 1.00)(\mathrm{p}<$ $0.0001)$ groups.

\section{EFFECTS OF TEBN AND CEBN ON TIME SPENT}

The effect of EBN on time taken to enter all four baited arms during acquisition and retention trials showed a significant 'within-group' difference in time spent during the acquisition phase among the rats fed with TEBN ( $p$ $<0.05$ ) (Figure 4(A)). However, no significant 'withingroup' difference was reported in the control and CEBN groups $(p>0.05)$. Across the groups, CEBN treated animals spent significantly more time in RAM compared to the control group on day $3(\mathrm{p}<0.01)$ and day $8(\mathrm{p}<$
0.01 ), and the TEBN group on day $3(\mathrm{p}<0.01)$. Similar to CEBN, on day 8 , the TEBN group significantly spent more time on RAM compared to the control animals ( $p$ $<0.01)$. There was no significant difference across the groups in retention trial (Figure 4(B)).

\section{EFFECTS OF TEBN AND CEBN ON PERCENTAGE OF CORRECT CHOICES}

For the percentage of correct choices of baited arms in the acquisition and retention trials, we noticed a significant 'within-group' difference in the correct choice acquisition from day 1 to day 8 among the control animals (time effect) $(p<0.01)$, but not within TEBN $(p>0.05)$ and 


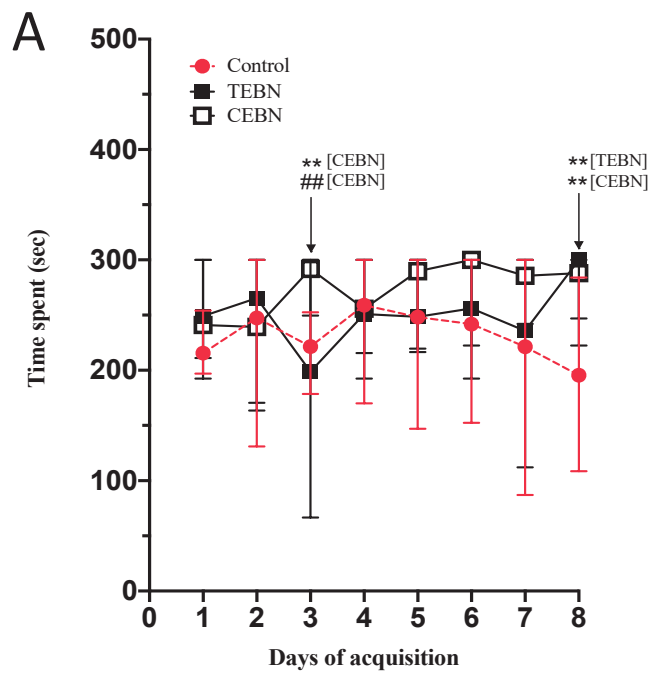

B

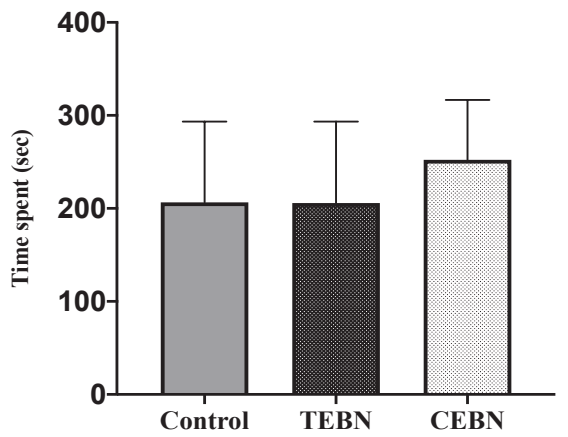

FIGURE 4. The effect of EBN on time spent in the spatial memory acquisition (A) and retention (B) trials. The ordinate axis is the median and lower (LL) and upper limit (UL) (Me [LL, UL]) of the total entries produced by rats in RAM. Friedman test was used to analyse significance within the groups. Kruskal-Wallis test showed significant changes in time spent for CEBN at days 3 and 8 , and TEBN at day $8 ; * *=p<0.01$ compared to control and $\# \#=p<0.01$ compared to TEBN by post hoc

Dunn's test. The time spent during retention trial was analysed by One-way ANOVA

CEBN ( $p>0.05$ ) groups (Figure 5(A)). Across the groups, the CEBN fed animals made significantly fewer correct choices compared to control and TEBN groups on day 3 $(\mathrm{p}<0.01)$. The EBN fed animals made significantly fewer correct choices compared to the control group on day 7 (TEBN vs control, $\mathrm{p}<0.05$; CEBN vs control, $\mathrm{p}<0.01$ ), and day 8 (TEBN vs control, $\mathrm{p}<0.05$; CEBN vs control, $\mathrm{p}$ $<0.05)$. For the retention trial, one-way ANOVA showed
A

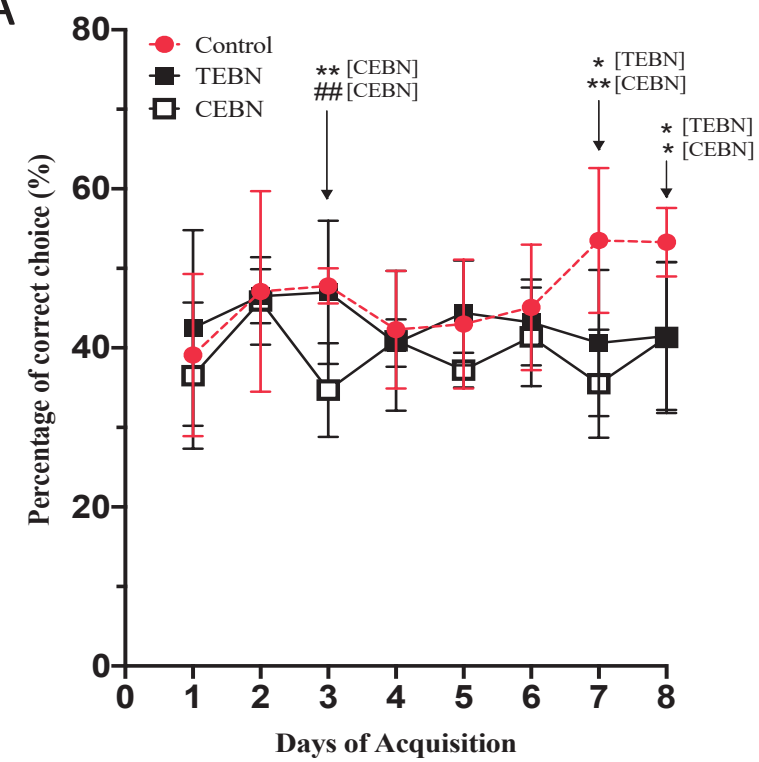

B

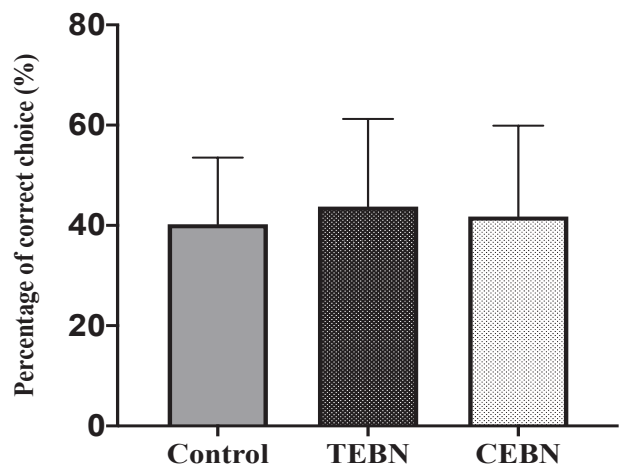

FIGURE 5. The effect of EBN on the percentage of correct choice in the spatial memory acquisition (A) and retention (B) trials. Repeated-measure of ANOVA was used to analyse the time effect and group interaction effects during the acquisition trial. Post hoc Bonferroni test showed significant changes in RME at days 3, 7 and 8; * $=\mathrm{p}<0.05, * *=\mathrm{p}<0.01$ compared to control and \#\#=p $<0.01$ compared to TEBN. The percentage of correct choice during retention trial was analysed by One-way ANOVA and showed no significant difference 
no significant difference in the percentage of correct choice among the groups $(\mathrm{p}>0.05)$ (Figure 5(B)).

\section{DISCUSSION}

In the present study, we investigated the effects of TEBN and CEBN on the spatial learning of male rats using RAM. The protocol employed to assess spatial learning was based on Valladolid-Acebes et al. (2011). In general, the control animals showed better learning responses compared to the other two groups during the acquisition trials, which was reflected through a clear descending pattern in the number of correct choices made, time spent finding all four baited arms and RME from day 4 to day 8 (Figures 2(A), 4(A) and 5(A)), and also based on the significant differences between the control and EBN treated groups in the percentage of correct choices (days 1 and 8), the time taken to visit all four baited arms (day 8) and RME (day 2).

Furthermore, CEBN profoundly reduced the WME during the acquisition (days 5 and 6) and retention trials, however, there was elevated RME during the retention trial. Previous studies have defined working memory as 'short-term memory' (Baddeley \& Hitch 1994) and reference memory as 'long-term memory' (Abrahams et al. 1997). The prefrontal cortex (PFC) was associated with working memory, and both PFC and hippocampus were implicated with reference memory (Murray et al. 2017) whereas retaining and acquiring new memory were mainly associated with the hippocampus (Debiec et al. 2002). The differential effects of CEBN that we noticed in the assessment of WME and RME could be attributed to its distinct mechanistic effects on different brain regions. In the present study, CEBN and TEBN reduced WME whereas CEBN increased RME during the retention trials. During the acquisition trials, CEBN improved WME (days 5 and 6) whereas TEBN improved RME (days 1 and 8), the time taken to find all four baited arms (day 3 ) and percentage of correct choice (day 3). Based on the findings, it can be surmised that CEBN worked better on WME compared to TEBN whereas TEBN-fed animals performed better than CEBN-fed animals in most of the parameters tested during the acquisition trials. Both EBNs were from a similar source of bird's nest, however they differed in preparation techniques. For instance, during the preparation, CEBN was steamed in one of the steps, but TEBN was not. Preparation of CEBN involved freeze-drying whereas TEBN was prepared using air-drying. Two of the most commonly associated compounds of EBN with cognitive function are $\mathrm{N}$-acetylglucosamine (GlcNAc) and sialic acid (SA). GlcNAc plays an important role in memory and cognitive functions through neuronal post-translational modification O-linked GlcNAc (O-GlcNAc) (Wheatley et al. 2019). GlcNAc is found in membrane proteins of brain microvascular endothelial cells (Prasadarao et al. 1996) and is also abundantly present in neurons (Zhu et al. 2014). SA is an essential component of brain gangliosides, important for brain cognitive functions and development (Yin et al. 2015). Exogenous sources of SA have been reported to improve spatial learning in various animal models (Khalid et al. 2019; Wang et al. 2007) in a dosedependent manner (Khalid et al. 2019). It is likely that steaming of EBN (as in CEBN) and freeze-drying (as in CEBN) may have altered the bioavailability of its effective compounds such as GlcNAc and SA. At this stage, we are still unable to confirm this, hence, future studies are needed to further investigate this notion. SA is widely used as conjugates for central nervous system novel drug delivery and further enhanced with GlcNAc modification, owing to their high abundance in the brain (Kuo et al. 2019; Prasadarao et al. 1996; Tosi et al. 2010). To the best of our knowledge, to date, no study has reported the biodistribution of an exogenous source of GlcNAc and SA from EBN in the central versus peripheral systems. Even so, given their outcomes on the cognitive performance and other neuroprotective effects of animals, we assume that these compounds are CNS penetrants.

Spatiotemporal assessments of animals in a behavioural apparatus are confounded by non-specific effects on their locomotion. In order to rule this out, we assessed the animals' locomotion through total entries produced during the acquisition and retention trials. We noticed no profound changes in the animals' locomotion during the acquisition trials, thus, it is safe to say that the effects of EBN observed during the acquisition trials were free of any confounding factors. However, during the retention trials, we noticed a significant reduction in total entries produced by CEBN-treated animals compared to the control and TEBN groups. CEBN group also lingered the longest (but not significantly) in the RAM during the retention trial, indicating a period of immobility during the study. Therefore, it is likely that the effects of CEBN we observed on WME and RME, during retention trials, were confounded by their lack of movement compared to the other two groups. On the contrary, we noticed no significant changes in locomotion of rats fed with TEBN during the retention trials. Hence, taken together, TEBN significantly reduced WME during the retention trial compared to the control and improved spatial learning during acquisition trials in comparison with the CEBN group.

One of the limitations of this study was that the 
amount of EBN consumed by each rat was not regulated, as the EBN was mixed in the pellets. We employed this procedure as we intended to mimic the human consumption of EBN as a food material. Therefore, to overcome this potential limitation in the future, an oral gavage technique could be considered to ensure each animal receives the same quantity of EBN. In this study, the recommended minimum dosage of EBN (300 mg/kg) was tested on the spatial learning of male rats. Spatial learning was greatly improved in cubs that were milked by lactating mice fed with high-dose EBN whereas cubs milked by lactating mice given mid and low dose EBN showed no significant improvements (Xie et al. 2018). In future studies, we recommend a higher dosage of EBN to be tested for a longer duration to investigate the potential beneficial effects of EBN in learning and memory.

\section{CONCLUSION}

TEBN generally improved spatial learning during the acquisition, and WME during retention trials. CEBN reduced WME during the acquisition and retention trials, however, this was confounded by its non-specific effects on animals' locomotion. Based on our findings, it appears that TEBN may improve the spatial learning of rats better compared to CEBN. The authors declare no conflict of interest.

\section{ACKNOWLEDGEMENTS}

This study was supported by the FF-2018-228. Fund provided by the Faculty of Medicine, Universiti Kebangsaan Malaysia (UKM). We would like to acknowledge Glycofood Sdn. Bhd. for providing the TEBN and CEBN.

\section{REFERENCES}

Abrahams, S., Pickering, A., Polkey, C.E. \& Morris, R.G. 1997. Spatial memory deficits in patients with unilateral damage to the right hippocampal formation. Neuropsychologia 35(1): 11-24.

Argüeso, P., Tisdale, A., Mandel, U., Letko, E., Foster, C.S. \& Gipson, I.K. 2003. The cell-layer-and cell-type-specific distribution of GalNAc-transferases in the ocular surface epithelia is altered during keratinization. Investigative Ophthalmology and Visual Science 44(1): 86-92.

Baddeley, A.D. \& Hitch, G.J. 1994. Developments in the concept of working memory. Neuropsychology 8(4): 485-493.

Chau, Q., Cantor, S.B., Caramel, E., Hicks, M., Kurtin, D., Grover, T. \& Elting, L.S. 2003. Cost-effectiveness of the bird's nest filter for preventing pulmonary embolism among patients with malignant brain tumors and deep venous thrombosis of the lower extremities. Supportive Care in Cancer 11(12): 795-799.
Chua, K.H., Mohamed, I.N., Mohd Yunus, M.H., Shafinaz Md Nor, N., Kamil, K., Ugusman, A. \& Kumar, J., 2021. The anti-viral and anti-inflammatory properties of Edible Bird's nest in influenza and coronavirus infections: From pre-clinical to potential clinical Application. Frontiers in Pharmacology 12: 1106 .

Debiec, J., LeDoux, J.E. \& Nader, K. 2002. Cellular and systems reconsolidation in the hippocampus. Neuron 36(3): 527 538.

Dhawan, S. \& Kuhad, R.C. 2002. Effect of amino acids and vitamins on laccase production by the bird's nest fungus Cyathus bulleri. Bioresource Technology 84(1): 35-38.

Halimi, N.M., Kasim, Z.M. \& Babji, A.S. 2014. Nutritional composition and solubility of edible bird nest (Aerodramus fuchiphagus). AIP Conference Proceedings 1614(1): 476481.

Hambali, A., Kumar, J., Hashim, N.F.M., Maniam, S., Mehat, M.Z., Cheema, M.S., Mustapha, M., Adenan, M.I., Stanslas, J. \&Hamid, H.A. 2021. Hypoxia-Induced neuroinflammation in Alzheimer's disease: Potential neuroprotective effects of Centella asiatica. Frontiers in Physiology 12: 712317.

Hamid, A.A., Aminuddin, A., Yunus, M.H.M., Murthy, J.K., Hui, C.K. \& Ugusman, A. 2020. Antioxidative and antiinflammatory activities of Polygonum minus: A review of literature. Reviews in Cardiovascular Medicine 21(2): 275-287.

Hodges, H. 1996. Maze procedures: The radial-arm and water maze compared. Cognitive Brain Research 3(3-4): 167181.

Hou, Z., He, P., Imam, M.U., Qi, J., Tang, S., Song, C. \& Ismail, M. 2017. Edible Bird's Nest prevents menopauserelated memory and cognitive decline in rats via increased hippocampal Sirtuin-1 expression. Oxidative Medicine and Cellular Longevity 2017: 7205082.

Kamil, K., Yazid, M.D., Idrus, R.B.H. \& Kumar, J. 2020. Hydroxytyrosol promotes proliferation of human schwann cells: An in vitro study. International Journal of Environmental Research and Public Health 17(12): 4404.

Kamil, K., Kumar, J., Yazid, M.D. \& Idrus, R.B.H. 2018. Olive and its phenolic compound as the promising neuroprotective agent. Sains Malaysiana 47(11): 2811-2820.

Kathan, R.H. \& Weeks, D.I. 1969. Structure studies of collocalia mucoid: I. Carbohydrate and amino acid composition. Archives of Biochemistry and Biophysics 134(2): 572-576.

Khalid, S.K.A., Abd Rashed, A., Aziz, S.A. \& Ahmad, H. 2019. Effects of sialic acid from edible bird nest on cell viability associated with brain cognitive performance in mice. World Journal of Traditional Chinese Medicine 5(4): 214-219.

Kuo, Y.C., Wang, L.J. \& Rajesh, R. 2019. Targeting human brain cancer stem cells by curcumin-loaded nanoparticles grafted with anti-aldehyde dehydrogenase and sialic acid: Colocalization of ALDH and CD44. Materials Science and Engineering C 102: 362-372.

Lee, P.L., Clayton, D.H., Griffiths, R. \& Page, R.D. 1996. Does behavior reflect phylogeny in swiftlets (Aves: Apodidae)? A test using cytochrome $b$ mitochondrial DNA 
sequences. Proceedings of The National Academy of Sciences 93(14): 7091-7096.

Lina, S., Eliza, H., Hashida, N.H., Ibrahim, S.F. \& Osman, K. 2018. Androgen receptor and ultrastructural features of Nigella sativa oil and nicotine-treated male rat reproductive glands. Sains Malaysiana 47(8): 1827-1833.

Marcone, M.F. 2005. Characterization of the edible bird's nest the "Caviar of the East". Food Research International 38(10): 1125-1134.

Matsukawa, N., Matsumoto, M., Bukawa, W., Chiji, H., Nakayama, K., Hara, H. \& Tsukahara, T. 2011. Improvement of bone strength and dermal thickness due to dietary edible bird's nest extract in ovariectomized rats. Bioscience Biotechnology and Biochemistry 75(3): 590-592.

Murray, J.D., Bernacchia, A., Roy, N.A., Constantinidis, C., Romo, R. \& Wang, X.J. 2017. Stable population coding for working memory coexists with heterogeneous neural dynamics in prefrontal cortex. Proceedings of The National Academy of Sciences 114(2): 394-399.

Ng, F., Wijaya, L. \& Tang, B.L. 2015. SIRT1 in the brain connections with aging-associated disorders and lifespan. Frontiers in Cellular Neuroscience 9: 64.

Norhayati, M.K., Azman, O. \& Nazaimoon, W.M. 2010. Preliminary study of the nutritional content of Malaysian edible bird's nest. Malaysian Journal of Nutrition 16(3): 389-396.

Prasadarao, N.V., Wass, C.A. \& Kim, K.S. 1996. Endothelial cell GlcNAc beta 1-4GlcNAc epitopes for outer membrane protein A enhance traversal of Escherichia coli across the blood-brain barrier. Infection and Immunity 64(1): 154160.

Prom-In, S., Kaewsrichan, J., Wangpradit, N., Kien Hui, C., Yahaya, M.F., Kamisah, Y. \& Kumar, J. 2020. Abelmoschus esculentus (1.) moench's peel powder improves high-fatdiet-induced cognitive impairment in C57BL/6J mice. International Journal of Environmental Research and Public Health 17(15): 5513.

Quillfeldt, J.A. 2016. Rodent Model as Tools in Ethical Biomedical Research: Behavioral Methods to Study Learning and Memory in Rats, edited by Andersen, M.L. \& Tufik, S. Cham: Springer. pp. 271-311.

Tosi, G., Vergoni, AV., Ruozi, B., Bondioli, L., Badiali, L., Rivasi, F., Costantino, L., Forni, F. \& Vandelli, M.A. 2010. Sialic acid and glycopeptides conjugated PLGA nanoparticles for central nervous system targeting: in vivo pharmacological evidence and biodistribution. Journal of Controlled Release 145(1): 49-57.
Valladolid-Acebes, I., Stucchi, P., Cano, V., Fernández-Alfonso, M.S., Merino, B., Gil-Ortega, M., Fole, A., Morales, L., Ruiz-Gayo, M. \& Del Olmo, N. 2011. High-fat diets impair spatial learning in the radial-arm maze in mice. Neurobiology of Learning and Memory 95(1): 80-85.

Wang, B., Yu, B., Karim, M., Hu, H., Sun, Y., McGreevy, P., Petocz, P., Held, S. \& Brand-Miller, J. 2007. Dietary sialic acid supplementation improves learning and memory in piglets. The American Journal of Clinical Nutrition 85(2): 561-569.

Wheatley, E.G., Albarran, E., White III, C.W., Bieri, G., SanchezDiaz, C., Pratt, K., Snethlage, C.E., Ding, J.B. \& Villeda, S.A. 2019. Neuronal O-GlcNAcylation improves cognitive function in the aged mouse brain. Current Biology 29(20): 3359-3369.

Xie, Y., Zeng, H., Huang, Z., Xu, H., Fan, Q., Zhang, Y. \& Zheng, B. 2018. Effect of maternal administration of edible bird's nest on the learning and memory abilities of suckling offspring in mice. Neural Plasticity 2018: 7697261.

Yin, T., Yang, L., Liu, Y., Zhou, X., Sun, J. \& Liu, J. 2015. Sialic acid (SA)-modified selenium nanoparticles coated with a high blood-brain barrier permeability peptide-B6 peptide for potential use in Alzheimer's disease. Acta Biomaterialia 25: 172-183.

Zhu, Y., Shan, X., Yuzwa, S.A. \& Vocadlo, D.J. 2014. The emerging link between O-GlcNAc and Alzheimer disease. The Journal of Biological Chemistry 289(50): 34472-34481.

Haziq Kamal, Khidhir Kamil, Nelson Tan Kar Wai, Abdul Latif Noor Bin Amiruddin, Manmeet Kaur Prithviraj Singh, Nurul Aina Binti Johaniff, Nursyahirah Binti Abdul Halim, Chua Kien Hui \& Jaya Kumar*

Department of Physiology, Faculty of Medicine Universiti Kebangsaan Malaysia Medical Centre 56000 Cheras, Kuala Lumpur, Federal Territory Malaysia

Azmawati Mohammed Nawi

Department of Community Health

Faculty of Medicine

Universiti Kebangsaan Malaysia Medical Centre 56000 Cheras, Kuala Lumpur, Federal Territory Malaysia

*Corresponding author; email: jayakumar@ukm.edu.my

Received: 23 April 2020

Accepted: 13 April 2021 